Supporting Information for

\title{
Directional Supramolecular Assembly of $\pi$-Amphiphiles with Tunable Surface Functionality and Impact on the Antimicrobial Activity
}

\author{
Amrita Sikder, ${ }^{\dagger}$ Jayita Sarkar ${ }^{\dagger}$ Ranajit Barman and Suhrit Ghosh* \\ School of Applied and Interdisciplinary Sciences, Indian Association for the Cultivation of Science, \\ 2A and 2B Raja S. C. Mullick Road, Kolkata, India-700032 \\ *Email: psusg2@iacs.res.in \\ ${ }^{\dagger}$ Contributed Equally
}

Materials: All reagents were purchased from Sigma Aldrich Chemical Co. and used without any further purification. Solvents were purchased from local chemical companies and purified by standard methods. ${ }^{1}$ HPLC grade solvents were used for UV/Vis, IR and Fluorescence spectroscopy studies. NMR spectra were recorded on a Bruker DPX- $300 \mathrm{MHz}, 400 \mathrm{MHz}$ or $500 \mathrm{MHz}$ NMR spectrometer and calibrated using TMS. MALDI-TOF experiment was done in Ultraflextreme mass spectrometer (Bruker Daltonics) equipped with Bruker smartbeam II 355 $\mathrm{nm}$ Nitrogen laser using dithranol as matrix. UV/Vis spectra were recorded at a Perkin Elmer Lambda 25 spectrometer. Fluorescence spectra were taken in a Fluorolog spectrophotometer from Horiba Jobin Yvon. TEM images were captured in JEOL-2010EX instrument operating at an accelerating voltage of $200 \mathrm{KV}$. ITC measurements were performed using a MicroCal -200ITC instrument. Fluorescence images were taken in Olympus IX73, Tokyo, Japan microscope.

\section{Synthesis and Characterization:}

NDI-1, NDI-3 and C-1 were prepared in multiple steps using the synthetic protocol as outlined in Scheme S1, Scheme S2 and Scheme S3 respectively. Synthesis of compound 1, 2 and 3 have been reported by us earlier. ${ }^{2}$ Control molecule $\mathrm{C}-2$ we have obtained a by-product during the synthesis of NDI-2 (reported previously). ${ }^{2}$ The final compounds were characterized by ${ }^{1} \mathrm{H}$ NMR, ${ }^{13} \mathrm{C}$ NMR and MALDI-TOF, melting point (MP) and UV-Vis spectroscopy. 

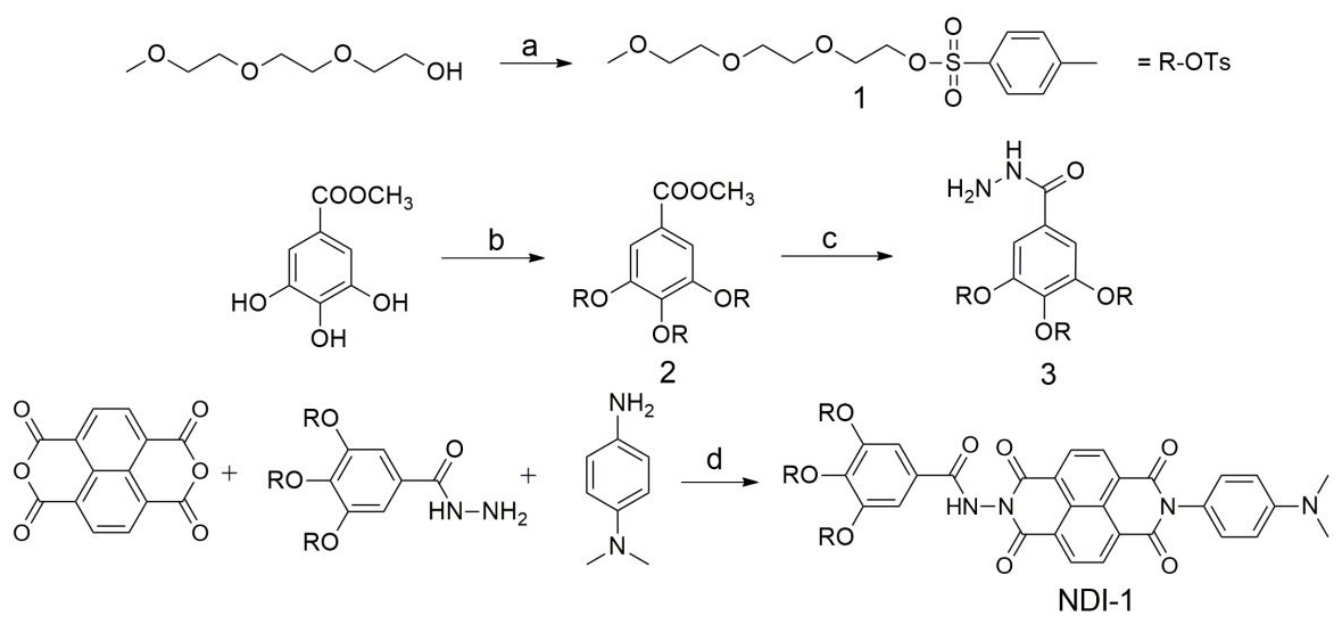

Reagents and conditions: (a) THF-water, $\mathrm{NaOH}$, 4-Toluenesulfonyl chloride, $0{ }^{\circ} \mathrm{C}, 5 \mathrm{~h}, 75 \%$; (b) $\mathrm{K}_{2} \mathrm{CO}_{3}, \mathrm{KI}, \mathrm{CH}_{3} \mathrm{CN}, 80{ }^{\circ} \mathrm{C} 48 \mathrm{~h}, 68 \%$; (c) Hydrazine hydrate, $\mathrm{MeOH}, 70{ }^{\circ} \mathrm{C}, 12 \mathrm{~h}, 80 \%$; d) a) DMF, $120^{\circ} \mathrm{C}, 36 \mathrm{~h}, 32 \%$.

Scheme S1. Synthesis of NDI-1

NDI-1: Commercially available $N, N$-dimethyl benzene 1-4 diamine (303 mg, $1.45 \mathrm{mM}$ )$\mathrm{HCl}$ salt was first neutralized by stirring with 2 equivalents of triethylamine in DMF for 1 h. To it 1,4,5,8- napthalenetetracarboxylic bisanhydride (390 mg, $1.45 \mathrm{mM}$ ) and compound 3 (900 mg, $1.45 \mathrm{mM}$ ) were added and the reaction mixture was stirred at 120 ${ }^{\circ} \mathrm{C}$ for $36 \mathrm{~h}$. After that, the reaction mixture was cooled to rt and the precipitate obtained was separated through filtration. The filtrate was evaporated to get a pasty mass, then it was redissolved in dichloromethane (DCM). Then the DCM solution was washed with water $(2 \times 20 \mathrm{~mL})$ and then with brine $(2 \times 20 \mathrm{~mL})$ and dried over anhydrous $\mathrm{Na}_{2} \mathrm{SO}_{4}$. 
Solvent was evaporated to get the crude product as a brown solid. It was purified by column chromatography using silica gel as a stationary phase and $\mathrm{CH}_{2} \mathrm{Cl}_{2} / \mathrm{MeOH}$ (98:2) as eluent to get the desired product as a light brown solid with $32 \%$ yield. MP $=193-195$ ${ }^{\circ} \mathrm{C} ;{ }^{1} \mathrm{H}$ NMR $\left(400 \mathrm{MHz}, \mathrm{DMSO}-\mathrm{D}_{6}\right.$ and TMS $): \delta(\mathrm{ppm})=11.39(1 \mathrm{H}, \mathrm{s}), 8.81-8.73(4 \mathrm{H}, \mathrm{dd})$,
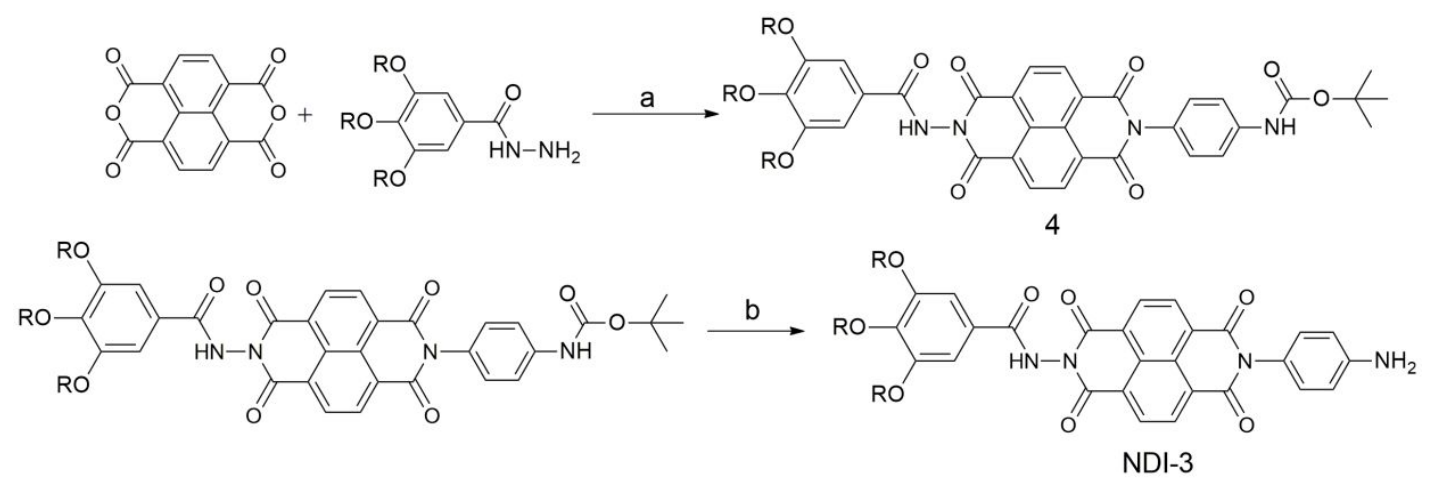

$7.37(2 \mathrm{H}, \mathrm{s}), 7.20(2 \mathrm{H}, \mathrm{d}), 6.83(2 \mathrm{H}, \mathrm{d}), 4.20-4.14(6 \mathrm{H}, \mathrm{m}), 3.85-3.26(39 \mathrm{H}, \mathrm{m}), 3.18$ $(6 \mathrm{H}$, s); ${ }^{13} \mathrm{C}$ NMR $\left(\mathrm{CDCl}_{3}\right)$ : 165.83 163.40, $161.14,152.67,150.84,143.07,131.73,131.39,128.83,127.67,127.30,127.04,126.77$ 126.32, 122.78,112.82, 109.11, 72.55 -70.39, 69.98, 69.45, 59.12, 40.6; MALDI-TOF: $\mathrm{m}$ / z calculated for $\mathrm{C}_{50} \mathrm{H}_{62} \mathrm{~N}_{4} \mathrm{O}_{17}[\mathrm{M}+\mathrm{Na}]^{+}:$1013.400; found:1013.399; $/ \mathrm{UV}$-Vis (THF): $376 \mathrm{~nm}\left(20714 \mathrm{M}^{-1} \mathrm{~cm}^{-1}\right), 356 \mathrm{~nm}\left(19122 \mathrm{M}^{-1} \mathrm{~cm}^{-1}\right), 338 \mathrm{~nm}\left(12357 \mathrm{M}^{-1} \mathrm{~cm}^{-1}\right) ;{ }^{1} \mathrm{H}-\mathrm{NMR}$, ${ }^{13} \mathrm{C}$ NMR and MALDI spectra are shown in Figure S9, S10 and S11, respectively. 
Reagents and conditions: (a) 4-(N-Boc-aminomethyl)aniline, DMF, $120^{\circ} \mathrm{C}, 36 \mathrm{~h}, 31 \%$; c) TFA, DCM, $0^{\circ} \mathrm{C}, 12 \mathrm{~h}, \mathrm{~K}_{2} \mathrm{CO}_{3} 98 \%$.

Scheme S2. Synthesis of NDI-3

Compound 4: Compound 3 (600 mg, $0.96 \mathrm{mM}$ ), 1,4,5,8- naphthalene-tetracarboxylicbisanhydride (258 $\mathrm{mg}, 0.96 \mathrm{mM})$ and commercially available $N$-(tert-Butoxycarbonyl)1,4-phenylenediamine ( $200 \mathrm{mg}, 0.96 \mathrm{mM}$ ) were taken together in a round bottom flask containing $15 \mathrm{~mL}$ dry DMF and the reaction mixture was stirred for $36 \mathrm{~h}$ at $120^{\circ} \mathrm{C}$. Then reaction was stopped, cooled to rt and DMF was evaporated under reduced pressure. The pasty mass was partly dissolved in $30 \mathrm{~mL}$ of DCM and the remaining solid was removed by filtration. The filtrate solution was washed with water $(3 \times 30 \mathrm{~mL})$ and then with brine $(30 \mathrm{~mL})$ and dried over anhydrous $\mathrm{Na}_{2} \mathrm{SO}_{4}$. Solvent was evaporated to get the crude product as a brown solid. It was purified by column chromatography using silica gel as a stationary phase and $\mathrm{CH}_{2} \mathrm{Cl}_{2} / \mathrm{MeOH}(98: 2)$ as eluent to get the desired product as light orange solid (31\% yield). ${ }^{1} \mathrm{H}$ NMR (400 MHz, DMSO-D6 and TMS): $\delta(\mathrm{ppm})=11.38(1 \mathrm{H}, \mathrm{s}), 9.51(1 \mathrm{H}, \mathrm{s}), 8.82-8.75(4 \mathrm{H}, \mathrm{dd}), 7.62(2 \mathrm{H}, \mathrm{d}), 7.38(2 \mathrm{H}, \mathrm{s}), 7.31$ $(2 \mathrm{H}, \mathrm{s}), 4.23-4.15(6 \mathrm{H}, \mathrm{m}), 3.82-3.23(39, \mathrm{~m}), 1.5(9 \mathrm{H}, \mathrm{s}) ;{ }^{13} \mathrm{C} \mathrm{NMR}\left(\mathrm{CDCl}_{3}\right): 165.54$ 
163.9, 160.8, 158.07, 152.32, 146.66,142.62, 131.84,131.20, 129.23, 127.52, 127.07, $126.02,125.85,125.03,116.35,108.37,80.05,72.39,70.70-70.30,69.84,69.13,58.99$, $58.91,39.01,30.02,28.03 ; \mathrm{MP}=174-176^{\circ} \mathrm{C} ; \mathrm{MALDI}-\mathrm{TOF}: \mathrm{m} / \mathrm{z}$ calculated for $\mathrm{C}_{53} \mathrm{H}_{66} \mathrm{~N}_{4} \mathrm{O}_{19}[\mathrm{M}+\mathrm{Na}]^{+}:$1085.447; found:1085.451; ${ }^{1} \mathrm{H}-\mathrm{NMR},{ }^{13} \mathrm{C}$ NMR and MALDI spectra are shown in Figure S12, S13 and S14, respectively.

NDI-3: Compound 4 (100 mg) was dissolved in $5 \mathrm{~mL}$ of dry DCM and stirred for $30 \mathrm{~min}$ at $0{ }^{\circ} \mathrm{C}$. To it, a solution of $0.5 \mathrm{~mL}$ of TFA in $1.0 \mathrm{~mL} \mathrm{DCM}$ was added slowly. The solution was stirred for $5 \mathrm{~h}$ at $0{ }^{\circ} \mathrm{C}$. Then to it 10 equivalents of $\mathrm{Na}_{2} \mathrm{CO}_{3}$ was added and stirred for another 30 minutes to neutralize the solution. Compound was extracted with DCM $(20 \mathrm{~mL})$ and washed with water $(2 \times 20 \mathrm{~mL})$ and solution was passed through $\mathrm{Na}_{2} \mathrm{SO}_{4}$ and evaporated to get NDI-3 as light brown solid (quantitative yield). ${ }^{1} \mathrm{H}$ NMR $(400 \mathrm{MHz}$, DMSO-D6 and TMS): $\delta(p p m)=11.35(1 \mathrm{H}, \mathrm{s}), 8.81-8.72(4 \mathrm{H}, \mathrm{dd}), 7.37(2 \mathrm{H}, \mathrm{s}), 7.03$ $(2 \mathrm{H}, \mathrm{d}), 6.69(2 \mathrm{H}, \mathrm{d}), 5.4(2 \mathrm{H}, \mathrm{bs}), 4.22-4.15(6 \mathrm{H}, \mathrm{m}), 3.8-3.23(39 \mathrm{H}, \mathrm{m}) ;{ }^{13} \mathrm{C}$ NMR $\left(\mathrm{CDCl}_{3}\right): 165.51, \quad 163.29, \quad 160.79, \quad 152.53,146.64,142.64,131.48,131.12,129.04$ $127.41,126.97,126.42,125.97,124.99,116.17,108.40,72.39,70.68-70.31,69.82$ 
69.13, 58.99, 58.91; MP=169-172 ${ }^{\circ} \mathrm{C}$; MALDI-TOF: $\mathrm{m} / \mathrm{z}$ calculated for $\mathrm{C}_{48} \mathrm{H}_{58} \mathrm{~N}_{4} \mathrm{O}_{17}[\mathrm{M}+$ $\mathrm{Na}^{+}$: 985.369; found: 985.313; ع/ UV-Vis (THF): $376 \mathrm{~nm}\left(19398 \mathrm{M}^{-1} \mathrm{~cm}^{-1}\right), 356 \mathrm{~nm}$ $\left(17908 \mathrm{M}^{-1} \mathrm{~cm}^{-1}\right), 338 \mathrm{~nm}\left(10981 \mathrm{M}^{-1} \mathrm{~cm}^{-1}\right) \cdot{ }^{1} \mathrm{H}-\mathrm{NMR},{ }^{13} \mathrm{C}$ NMR and MALDI spectra are shown in Figure S15, S16 and S17, respectively.

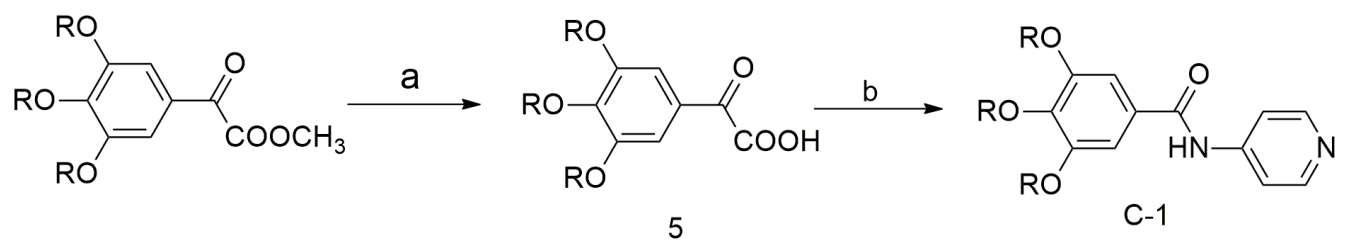

Scheme S3. Synthesis of C-1

Reagents and conditions: (a) $\mathrm{KOH}$, ethanol/water, $90^{\circ} \mathrm{C}, 5 \mathrm{~h}$, quantitative yield; (b) $\mathrm{CH}_{3} \mathrm{CN}$, EDC, DMAP, 4 -amino pyridine, $0{ }^{\circ} \mathrm{C}$-rt, $34 \mathrm{~h}, 48 \%$.

Compound 5: A solution of compound $2(1.12 \mathrm{~g}, 1.8 \mathrm{mmol})$ in $5 \mathrm{~mL}$ ethanol was added with aqueous $\mathrm{KOH}$ solution $\left(680 \mathrm{mg}, 12 \mathrm{mmol}\right.$ in $7 \mathrm{~mL}$ ) and the reaction mixture was stirred at $90{ }^{\circ} \mathrm{C}$ for $5 \mathrm{~h}$. The reaction was stopped, cooled to rt and acidified by cold dilute $\mathrm{HCl}$ solution. Then the product was extracted with ethyl-acetate and dried over $\mathrm{Na}_{2} \mathrm{SO}_{4}$ to get the pure product as light brown viscous liquid (quantitative yield). It was taken to the next step without further purification. ${ }^{1} \mathrm{H}$ NMR $\left(300 \mathrm{MHz}, \mathrm{CDCl}_{3}, \mathrm{TMS}\right): \delta(\mathrm{ppm})=7.344(\mathrm{~s}, 2 \mathrm{H}), 4.245(\mathrm{t}, 6 \mathrm{H}), 3.9-3.5$ (m, 30H), $3.38(\mathrm{~s}, 9 \mathrm{H})$.

Compound C-1: Compound 5 (600 mg, $0.986 \mathrm{mmol})$, 4-Aminopyridine (92 mg, $0.986 \mathrm{mmol}$ ) and $\mathrm{N}, \mathrm{N}$-dimethyl amino pyridine $(240 \mathrm{mg}, 1.97 \mathrm{mmol})$ were taken in dry $\mathrm{CH}_{3} \mathrm{CN}(10 \mathrm{~mL})$ and stirred for 15 minutes at $0{ }^{\circ} \mathrm{C}$. Then 1-Ethyl-3-(3-dimethylaminopropyl) carbodiimide (305mg, 
$2.4 \mathrm{mmol}$ ) was added to the reaction mixture and stirred for $24 \mathrm{~h}$. This crude mixture was extracted with water and ethyl-acetate. Organic layer was dried over $\mathrm{Na}_{2} \mathrm{SO}_{4}$ and solvent was evaporated to get the crude product as an oil. It was purified by column chromatography using silica gel as the stationary phase and $5 \%(\mathrm{v} / \mathrm{v})$ methanol in DCM as eluent to get the desired product as a viscous liquid (yield 48\%). ${ }^{1} \mathrm{H}$ NMR (400 $\left.\mathrm{MHz}, \mathrm{CDCl}_{3}\right) \delta(\mathrm{ppm})=9.74(\mathrm{~s}, 1 \mathrm{H})$, $8.41(\mathrm{~d}, 2 \mathrm{H}), 7.72(\mathrm{~s}, 2 \mathrm{H}), 7.21(\mathrm{~d}, 2 \mathrm{H}), 4.22(\mathrm{t}, 6 \mathrm{H}) 3.8-3.23(\mathrm{~m}, 39 \mathrm{H}) .{ }^{13} \mathrm{C}-\mathrm{NMR}\left(\mathrm{CDCl}_{3}\right) \delta=$ $166.45,152.34,150.16,141.82,129.35,114.31,108.13,72.89,72.70,72.63,72.41,70.35,70.2$ 69.99, 69.70, 69.04, 61.50, 58.1. ${ }^{1} \mathrm{H}-\mathrm{NMR}$ and ${ }^{13} \mathrm{C}$ NMR spectra are shown in Figure S18 and S19, respectively.

Compound C-2: Compound C-2 was obtained as a by-product during the synthesis of ND-2 which was reported by us elsewhere. ${ }^{2}$ In this reaction, 1,4,5,8- napthalenetetracarboxylic bisanhydride, compound 3, and 4-amino pyridine were taken together in a round bottom flask containing dry DMF and the reaction mixture was stirred for $24 \mathrm{~h}$ at $120{ }^{\circ} \mathrm{C}$. Subsequently when it was cooled solid precipitate came out which was filtered and washed with cold DMF, water, acetone and DCM (20 mL of each). The product was subsequently dried under vacuum to yield C-2 as a light brown solid. ${ }^{1} \mathrm{H}-\mathrm{NMR}(400 \mathrm{MHz}, \mathrm{DMSO}-\mathrm{d}$ ) $): \delta 8.71$ (d, 4H), $8.74(\mathrm{~s}, 4 \mathrm{H}), 7.53$ (d, 4H). ${ }^{13} \mathrm{C}$-NMR spectrum could not be recorded as the compound formed gel with subsequent precipitation in DMSO-D6 at higher concentration. ${ }^{1} \mathrm{H}-\mathrm{NMR}$ is spectrum is shown in Figure S20.

\section{Additional Figures:}

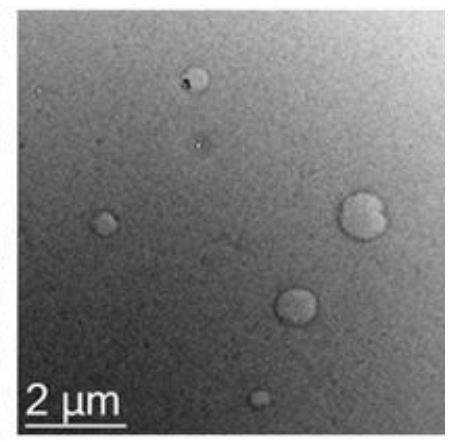




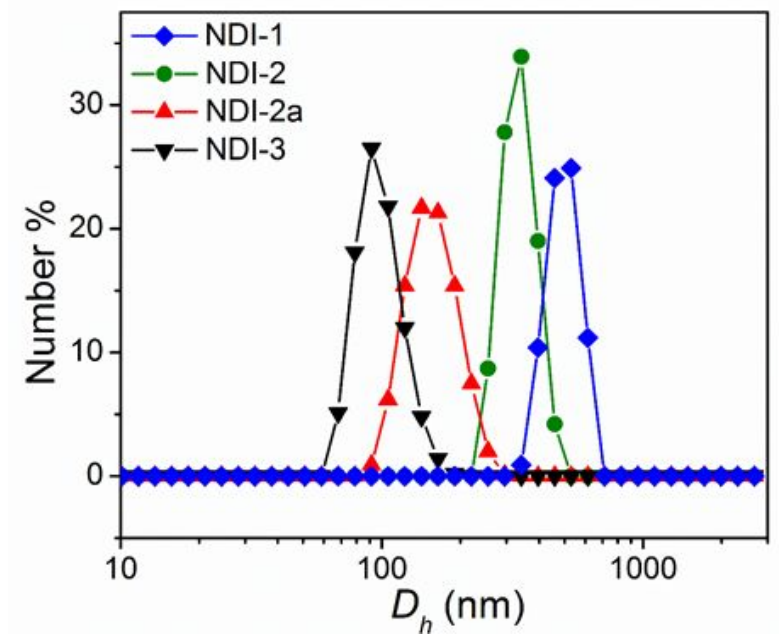

Figure S1. HR-TEM images of NDI-1, $C=1.5 \mathrm{mM}$.

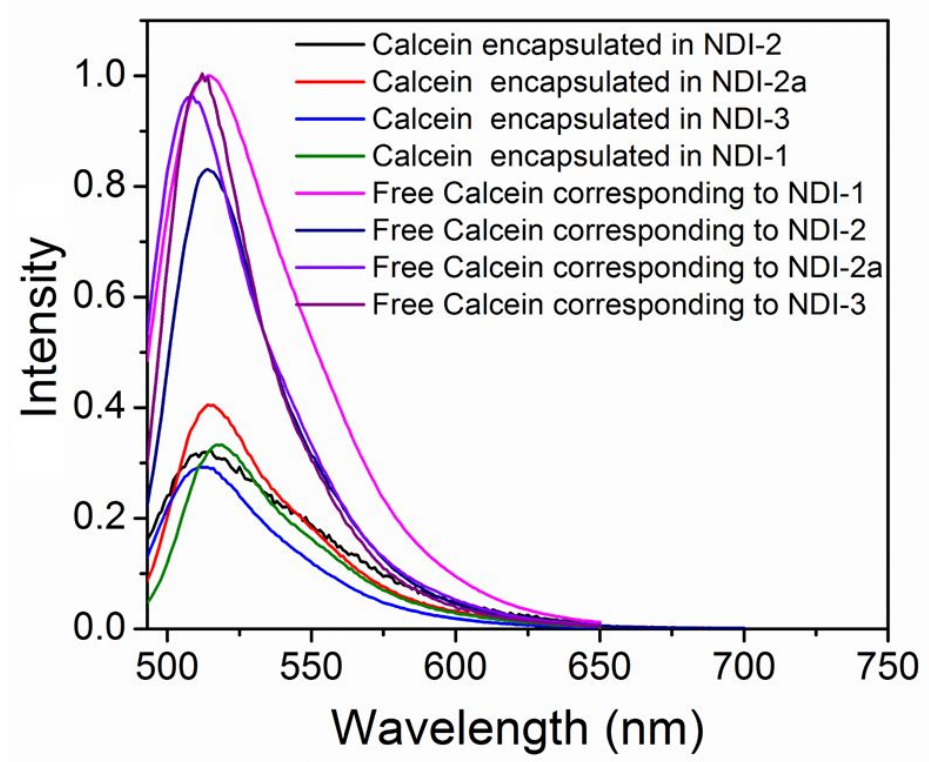

Figure S2. Particle size distribution of the aggregates obtained from DLS $(C=1.5 \mathrm{mM})$.

Figure S3: Fluorescence spectra of Calcein encapsulated in NDI-vesicles and corresponding free Calcein of same concentration $\left(\lambda_{\mathrm{ex}}=480 \mathrm{~nm}\right.$, Slit=2.5). 

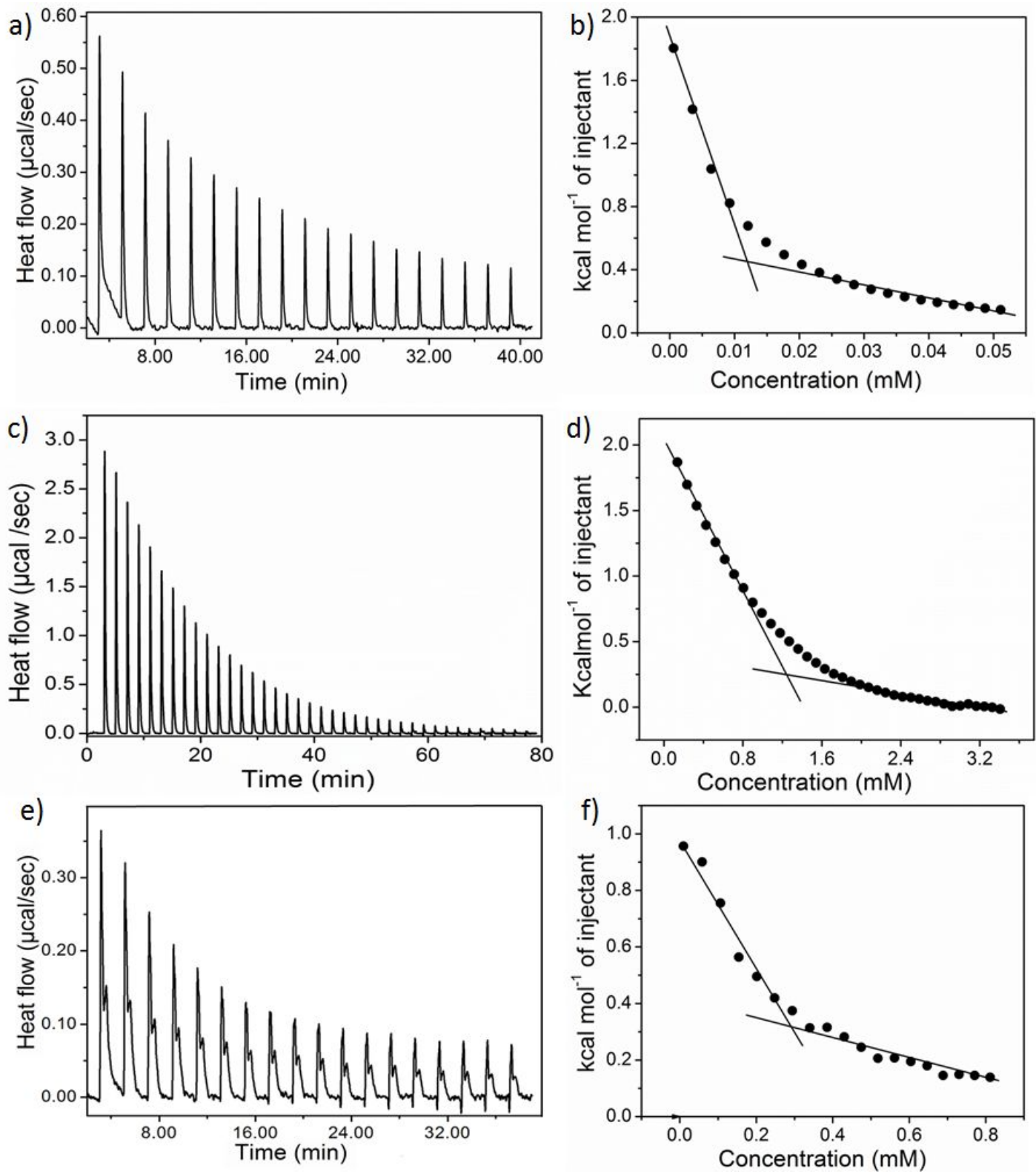

Figure S4: Heat release per injection of an aqueous solution of (a) NDI-2, (c) NDI-2a and (e) NDI-3 and their corresponding enthalpogram ( $b, d$, $f$ for NDI-2, NDI-2a and NDI-3, respectively); Stirring speed $=500 \mathrm{rpm}, T=25^{\circ} \mathrm{C}$. 

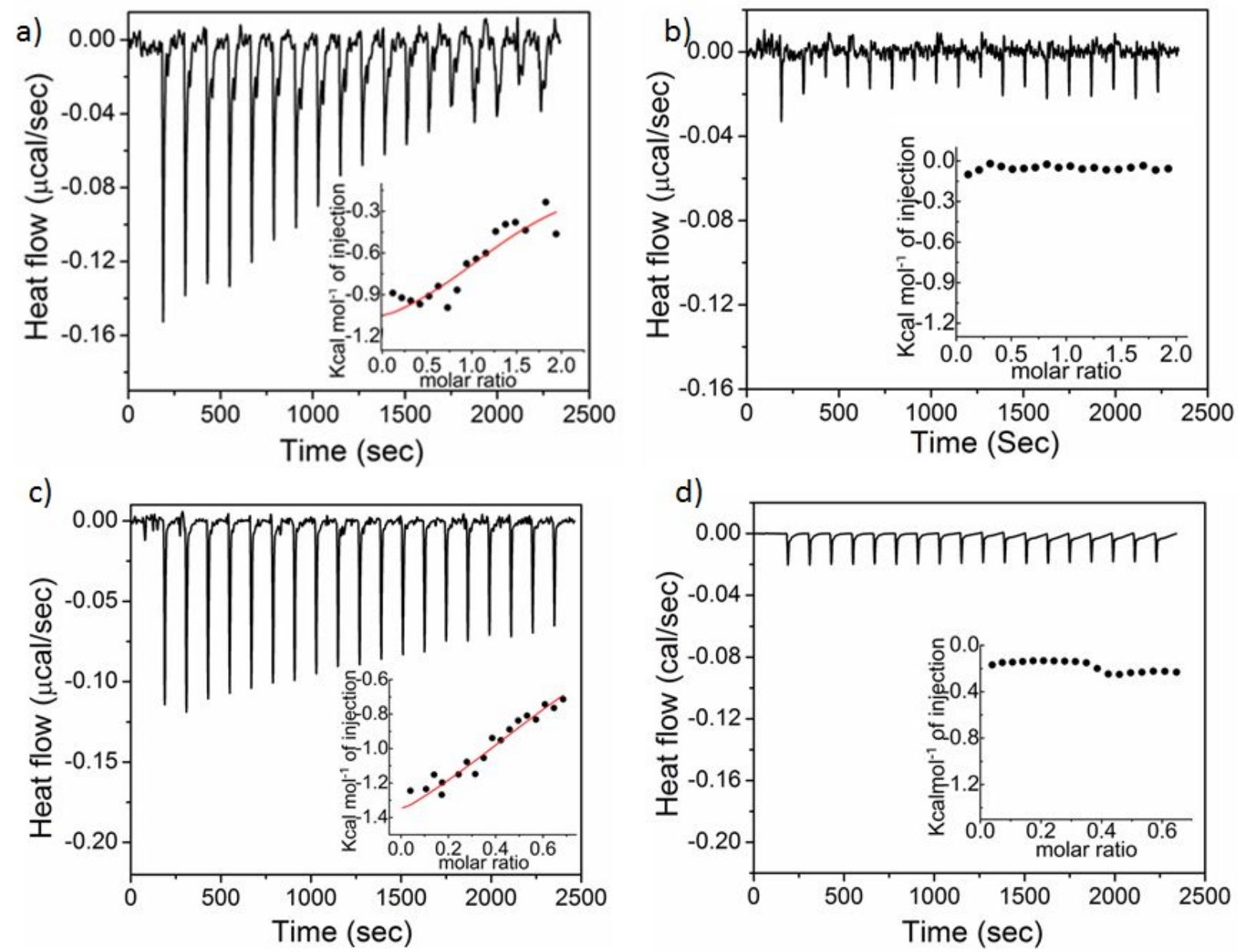

Figure S5: Isothermal titration calorimetry (ITC) thermograms of NDI-2 and NDI-3 with a-c) DPPG: DPPE (88: 12) and b-d) DPPC. Insets show corresponding enthalpogram. All the experiments were conducted at $37^{\circ} \mathrm{C}$ in $10 \mathrm{mM}$ HEPES buffer. Lipid concentration is $1.0 \mathrm{mM}$ and concentration of NDI-1 and NDI-3 are $0.1 \mathrm{mM}$ and $0.3 \mathrm{mM}$, respectively. These concentration ranges were chosen to keep the final concentration of NDI-amphiphile above CAC. Volume per Injection $=2 \mu \mathrm{L}$, stirring speed $=500 \mathrm{rpm}$. In figures $\mathrm{c}$ ) and $\mathrm{d}$ ) mole ratio (NDI/ lipid) could not be increased beyond 0.66 due to precipitation problem as in this case the total concentration had to be increased to ensure that the experiment was performed above the CAC of the respective NDI amphiphiles. 

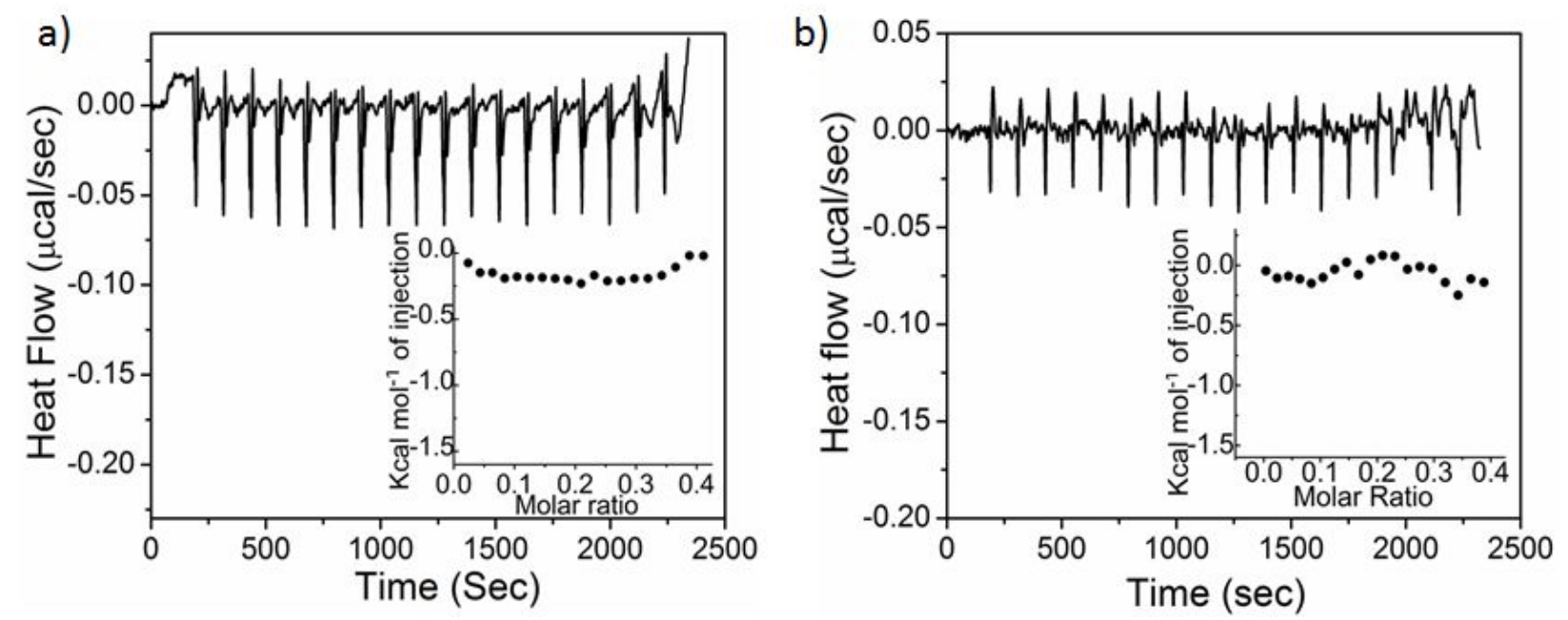

Figure S6: a) Isothermal titration calorimetry (ITC) thermograms of NDI-2a with a) DPPG: DPPE (88: 12) and b) with DPPC. Insets show corresponding enthalpogram. All the experiments were conducted at $37{ }^{\circ} \mathrm{C}$ in $10.0 \mathrm{mM}$ HEPES buffer. Lipid concentration is $2.0 \mathrm{mM}$ and NDI-2a concentration $1.1 \mathrm{mM}$. Volume per Injection $=2 \mu \mathrm{L}$, stirring speed=500 rpm.

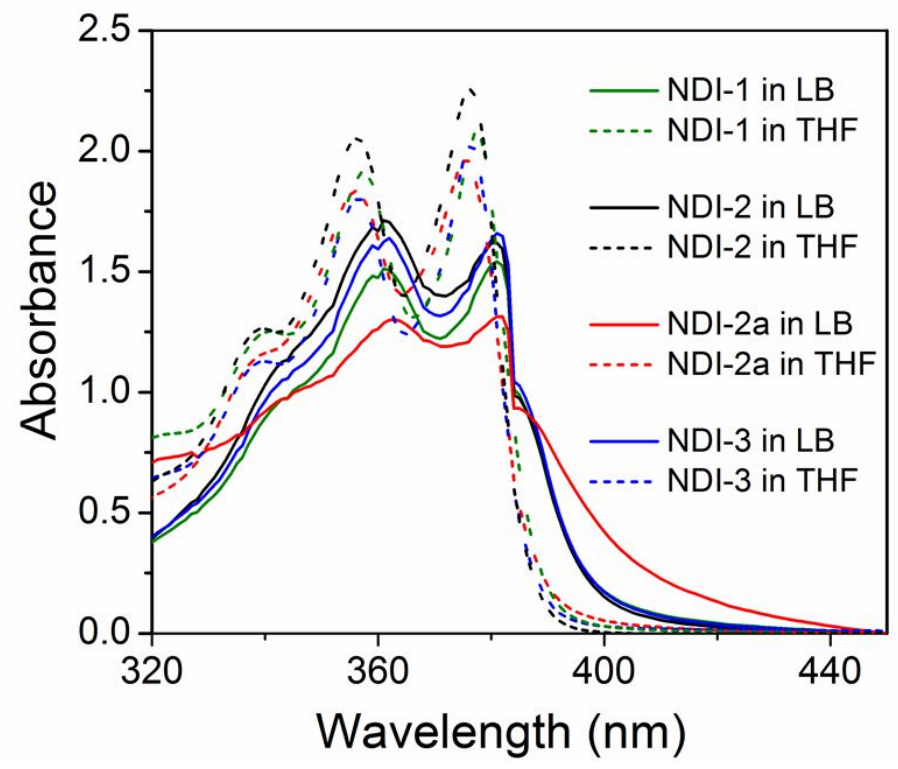

Figure S7: UV/Vis spectra of NDI amphiphiles $(C=1.5 \mathrm{mM}, l=0.1 \mathrm{~cm})$ in THF and in bacteria culture medium (Luria-Bertani broth). It shows intact aggregation in LB broth as the spectrum is distinctly different than the monomeric spectrum and the ratio of 
intensities of the two vibronic peaks are reversed which is a signature of self-assembly NDI.

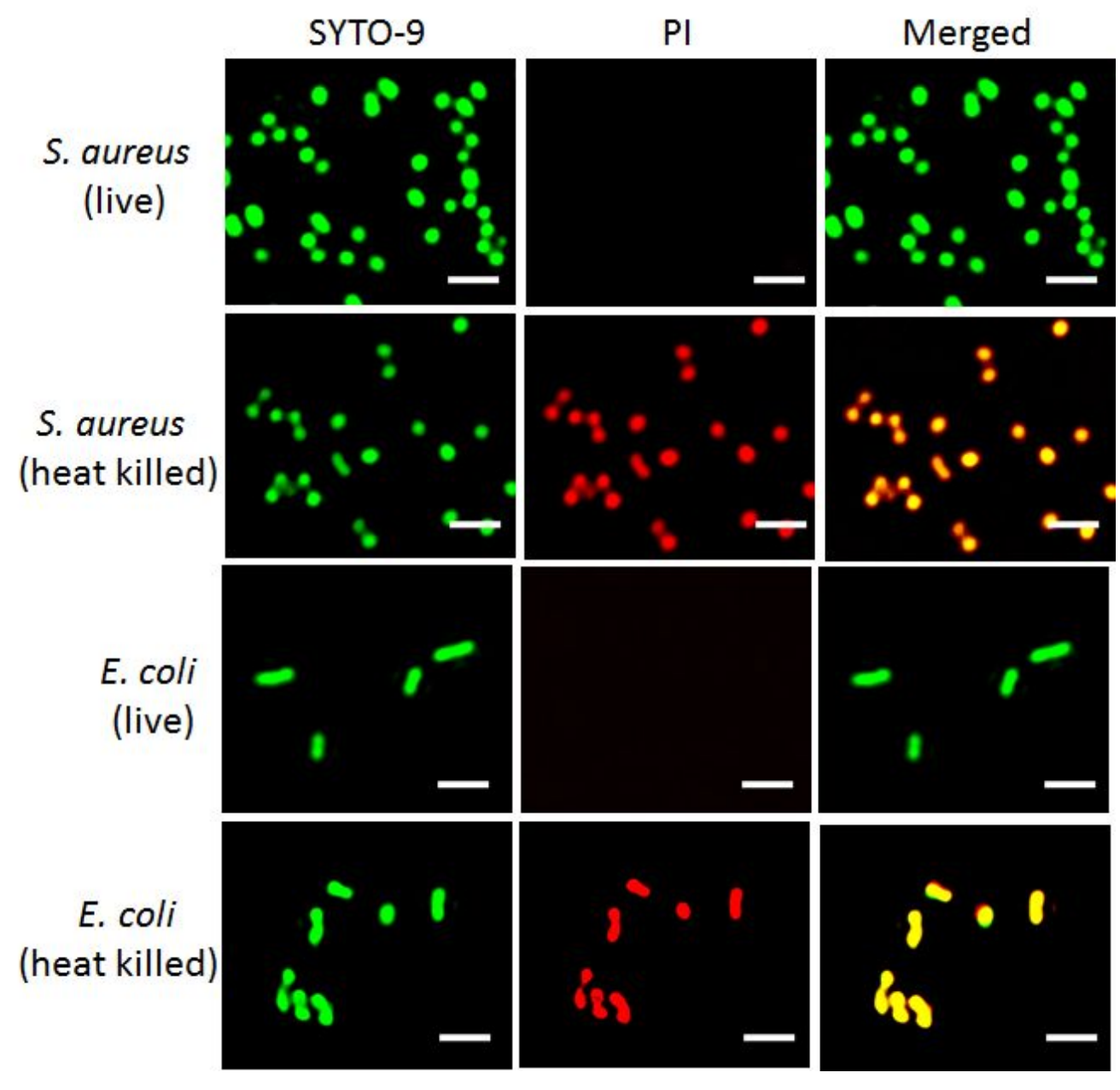

Figure S8: Fluorescence microscopy of S. aureus and E. coli before and after exposure to heat. Green channel is SYTO-9 nucleic acid stain, red channel is propidium iodide (PI) which only enters membrane-compromised bacteria and their merged image. Scale bar is $2 \mu \mathrm{m}$. 


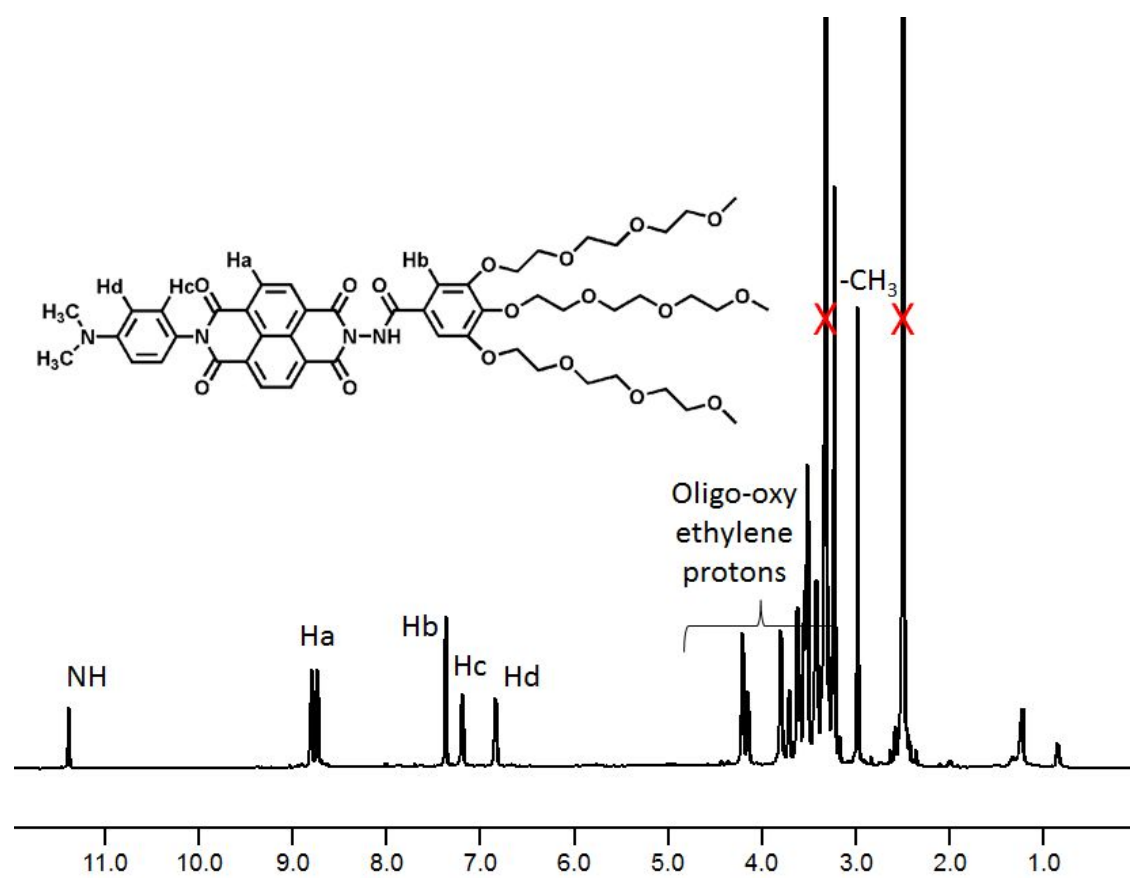

Figure S9: ${ }^{1} \mathrm{H}$ NMR spectra of NDI-1 (solvent DMSO-D6). X indicates solvent peak.

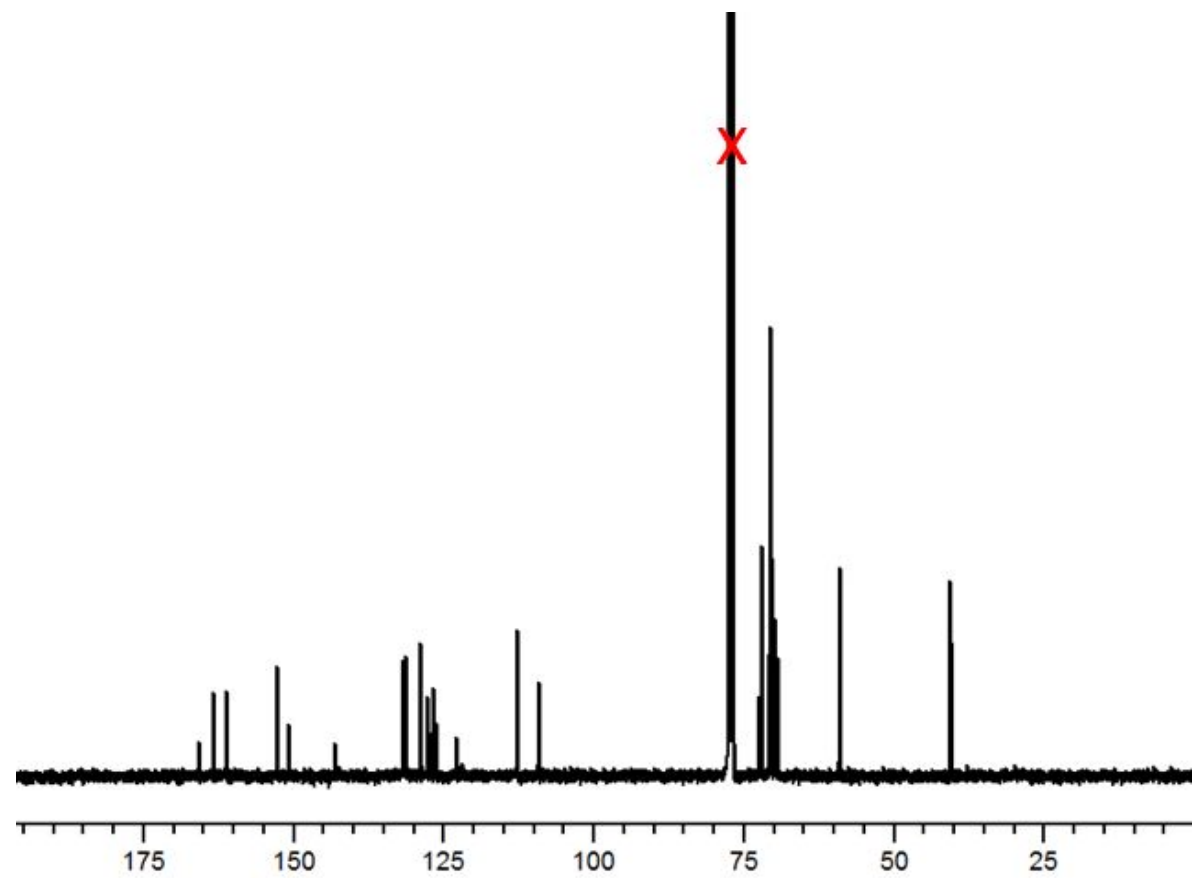

Figure S10: ${ }^{13} \mathrm{C}$ NMR spectra of NDI-1 (solvent $\mathrm{CDCl}_{3}$ ). $\mathrm{X}$ indicates solvent peak. 


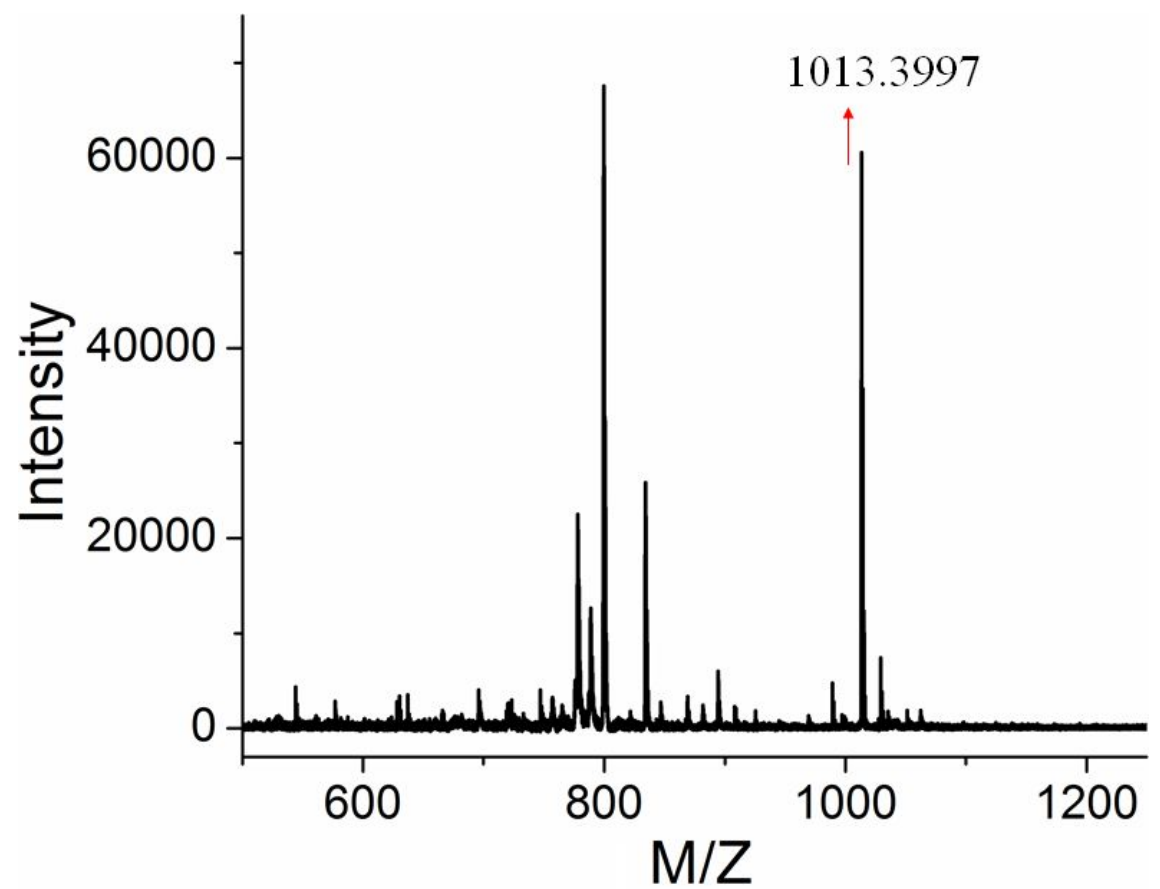

Figure S11: MALDI-TOF mass spectra of NDI-1(matrix used -dithranol).

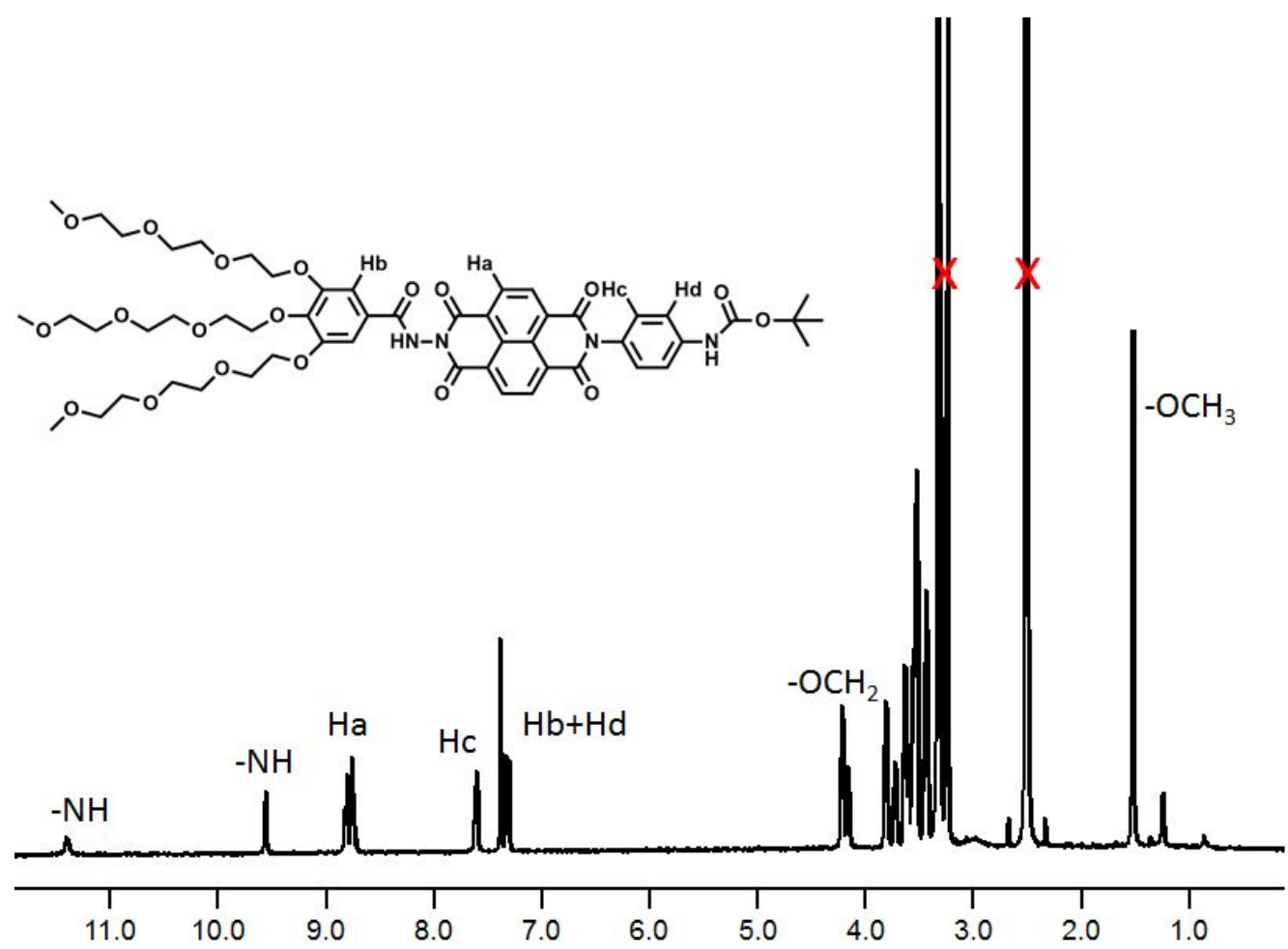

Figure S12: ${ }^{1} \mathrm{H}$ NMR spectra of compound 4 (solvent DMSO-D6). X indicates solvent peak. 


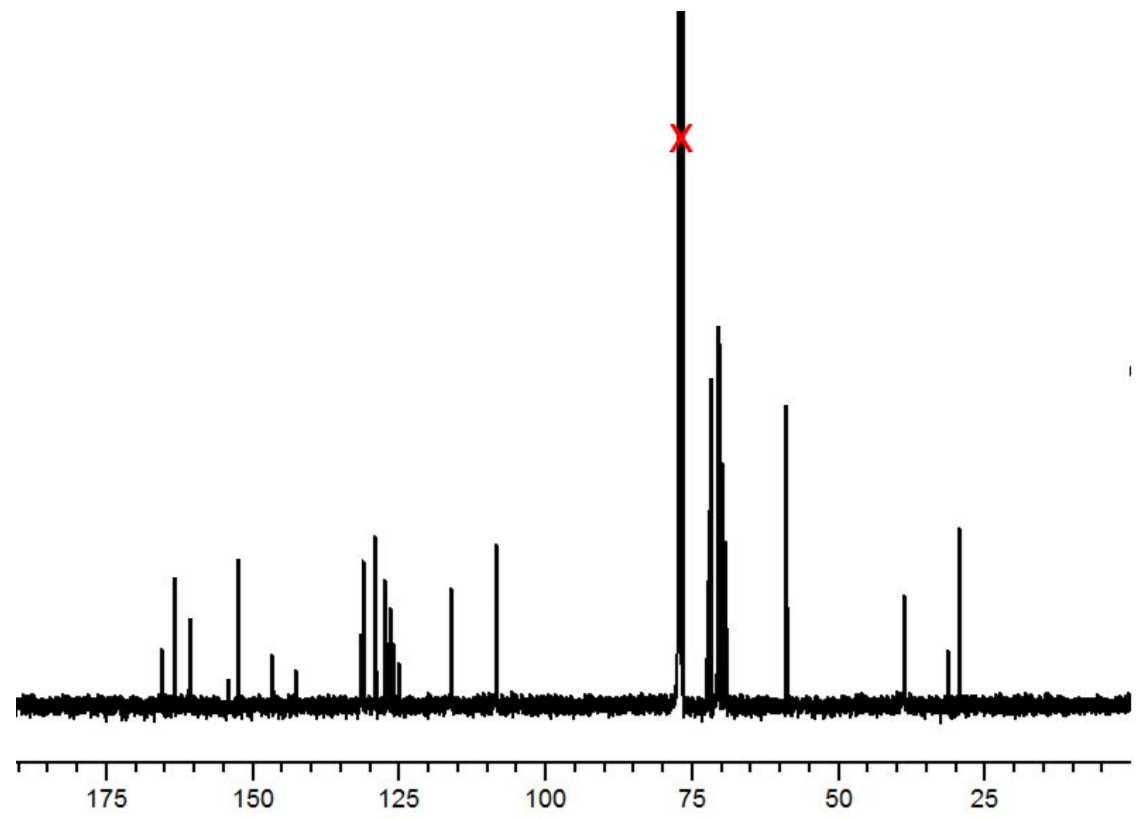

Figure S13: ${ }^{13} \mathrm{C}$ NMR spectra of compound 4 (solvent $\mathrm{CDCl}_{3}$ ). $\mathrm{X}$ indicates solvent peak.

Figure S14: MALDI-TOF mass spectra of compound 4 (matrix used -dithranol).

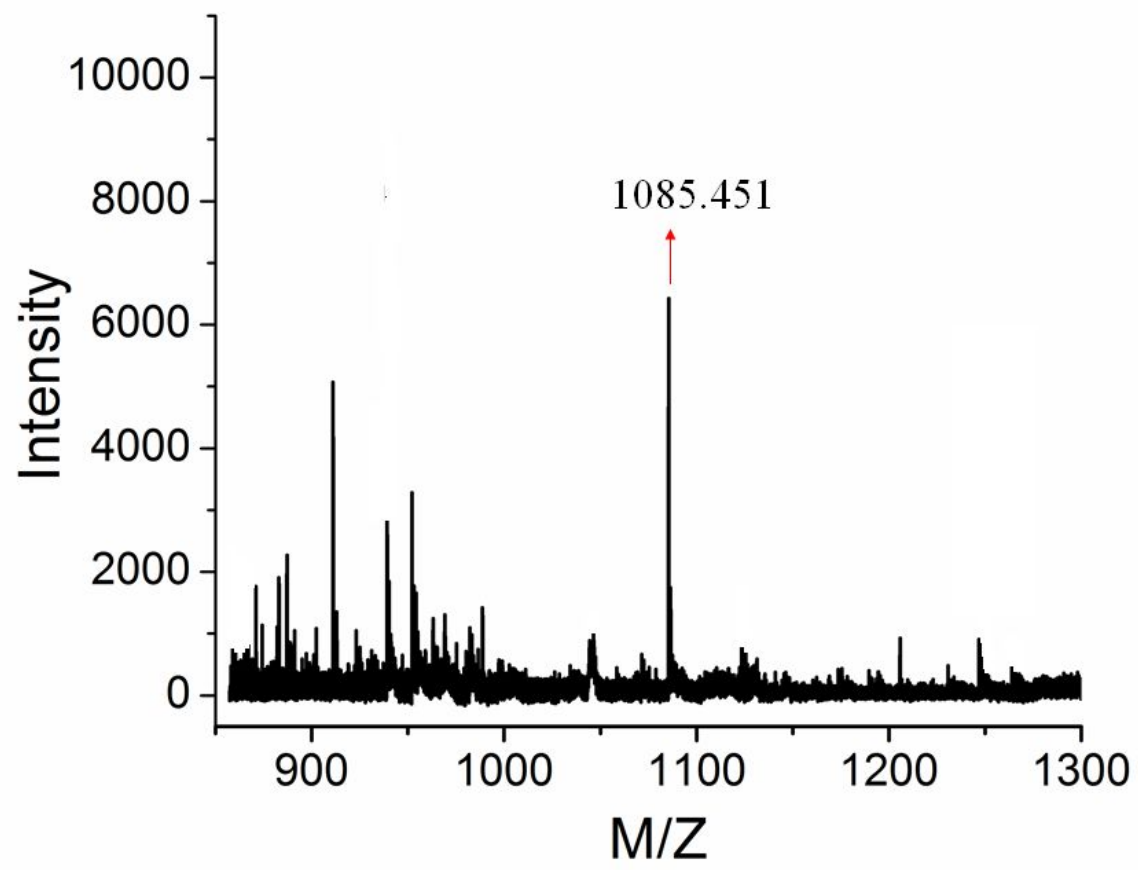




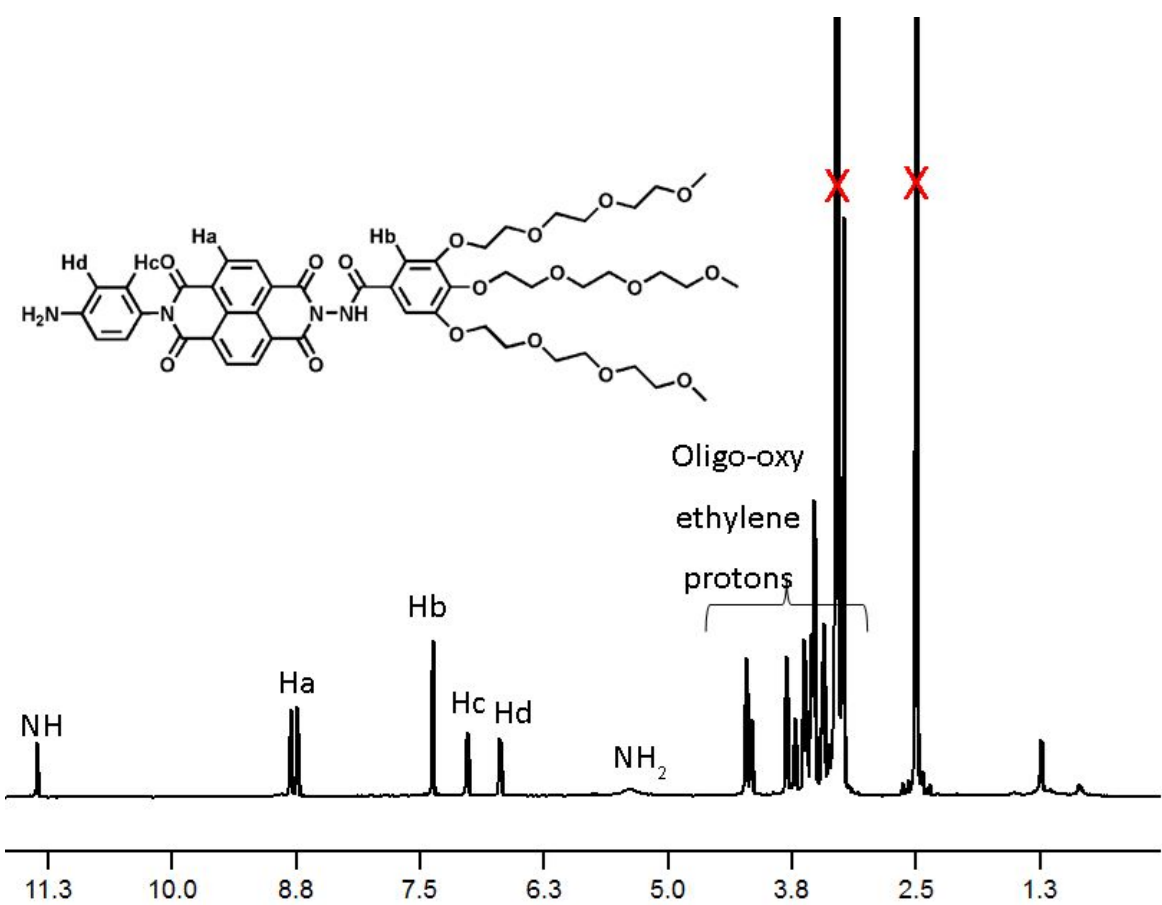

Figure S15: ${ }^{1} \mathrm{H}$ NMR spectra of NDI-3 (solvent DMSO-D6). X indicates solvent peak.

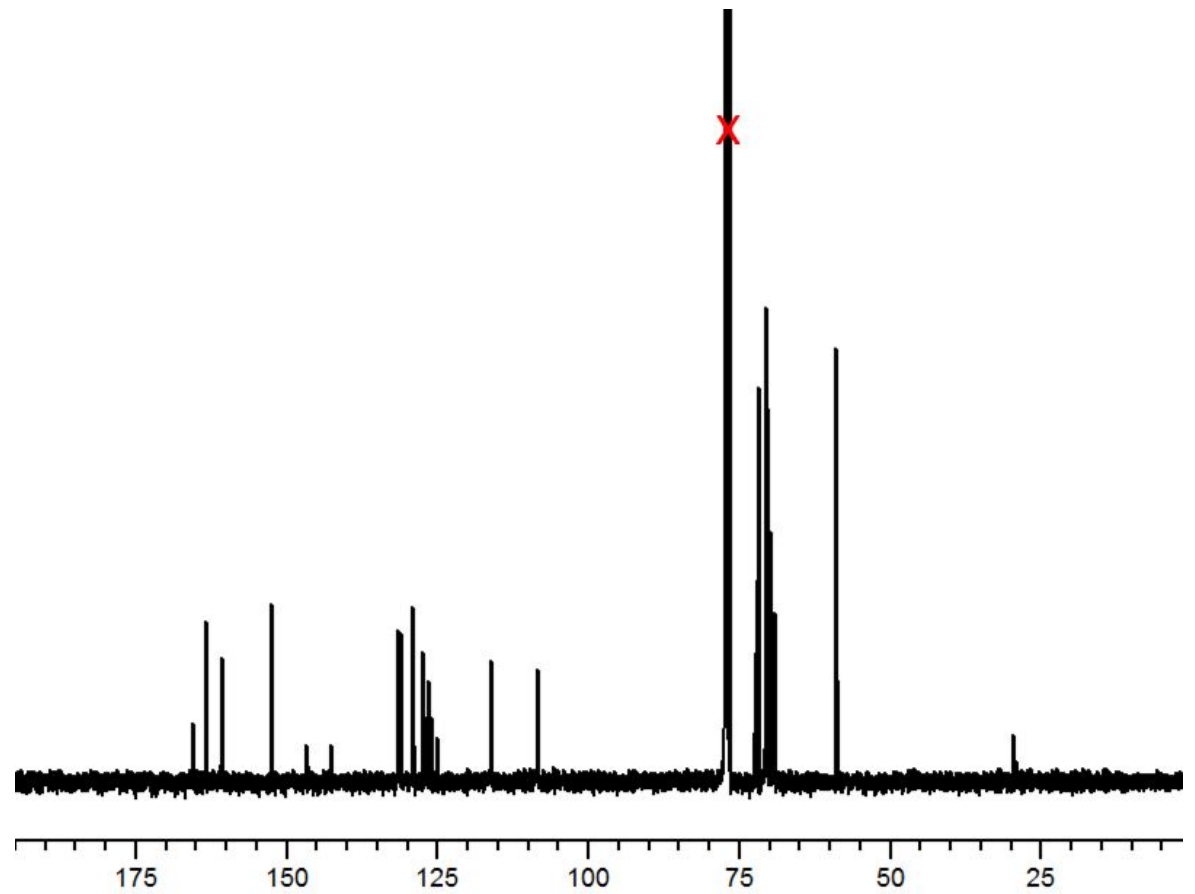

Figure S16: ${ }^{13} \mathrm{C}$ NMR spectra of NDI-3 (solvent $\mathrm{CDCl}_{3}$ ). $\mathrm{X}$ indicates solvent peak. 


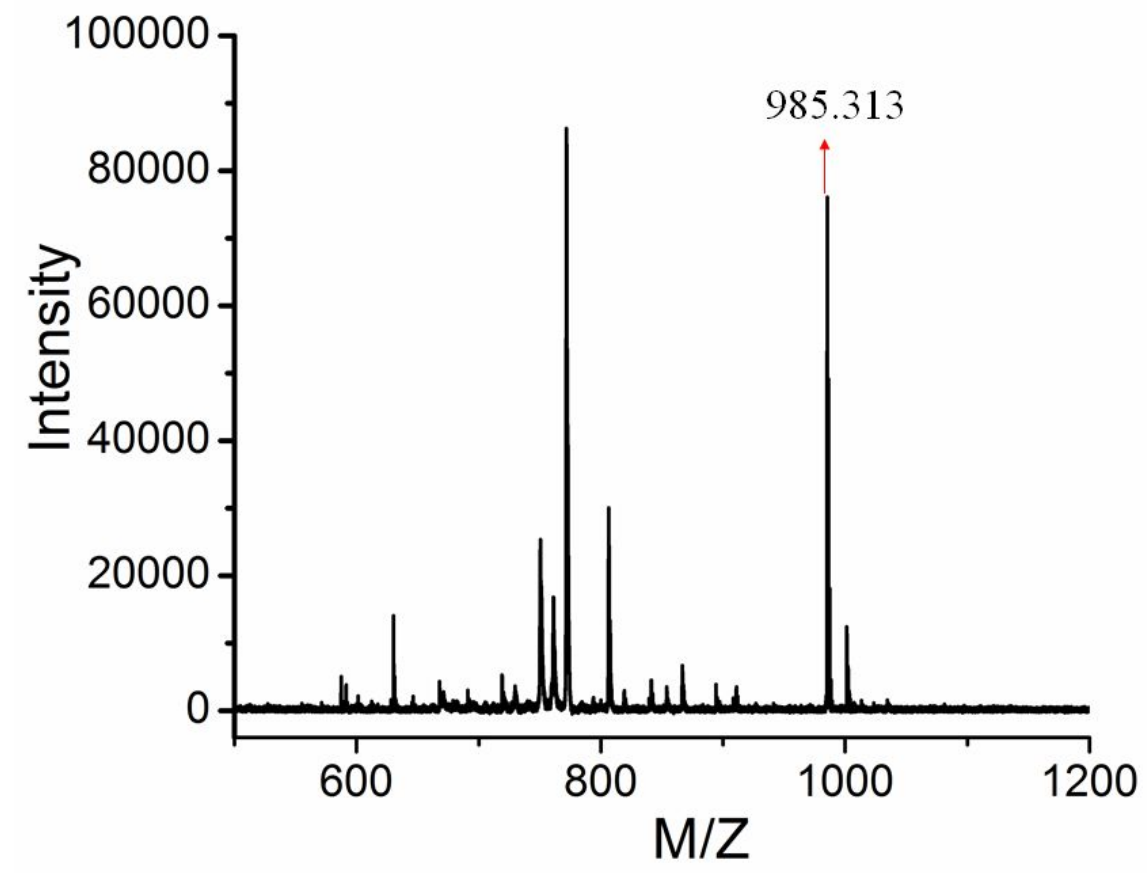

Figure S17: MALDI-TOF mass spectra of NDI-3 (matrix used -dithranol).

Figure S18: ${ }^{1} \mathrm{H}$ NMR spectra of $\mathrm{C}-1$ (solvent $\mathrm{CDCl}_{3}$ ). $\mathrm{X}$ indicates solvent peak.

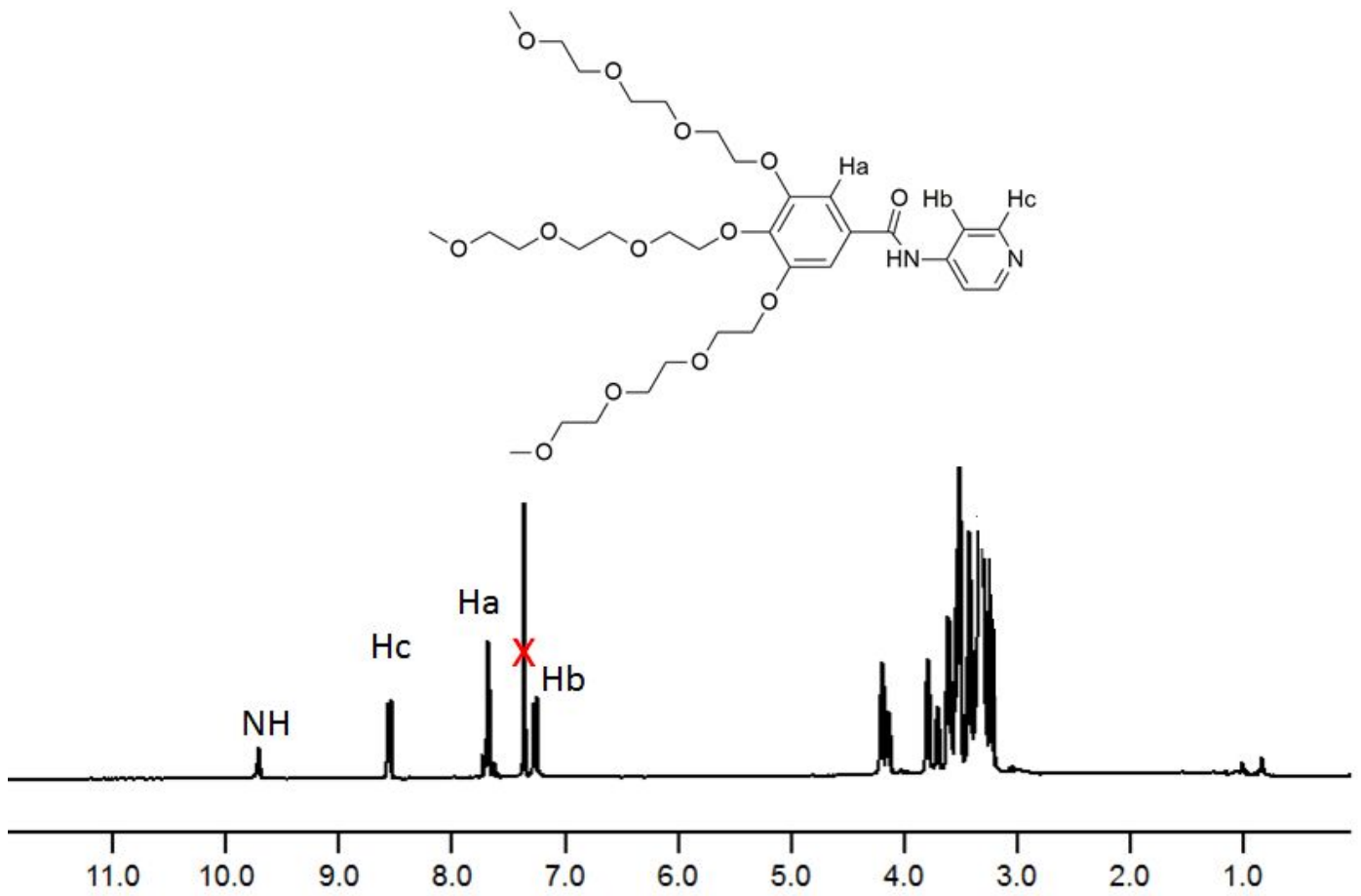




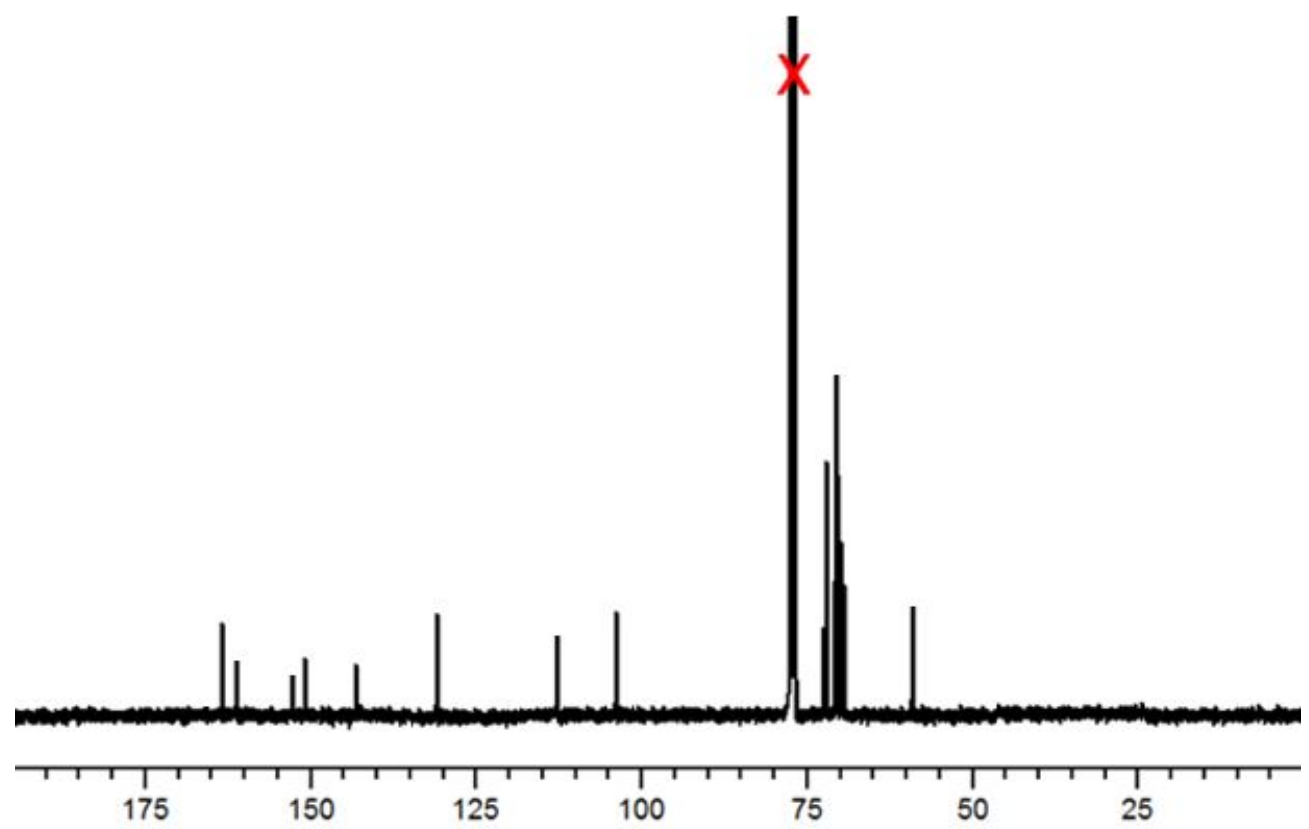

Figure S19: ${ }^{13} \mathrm{C}$ NMR spectra of $\mathrm{C}-1$ (solvent $\left.\mathrm{CDCl}_{3}\right)$. X indicates solvent peak.
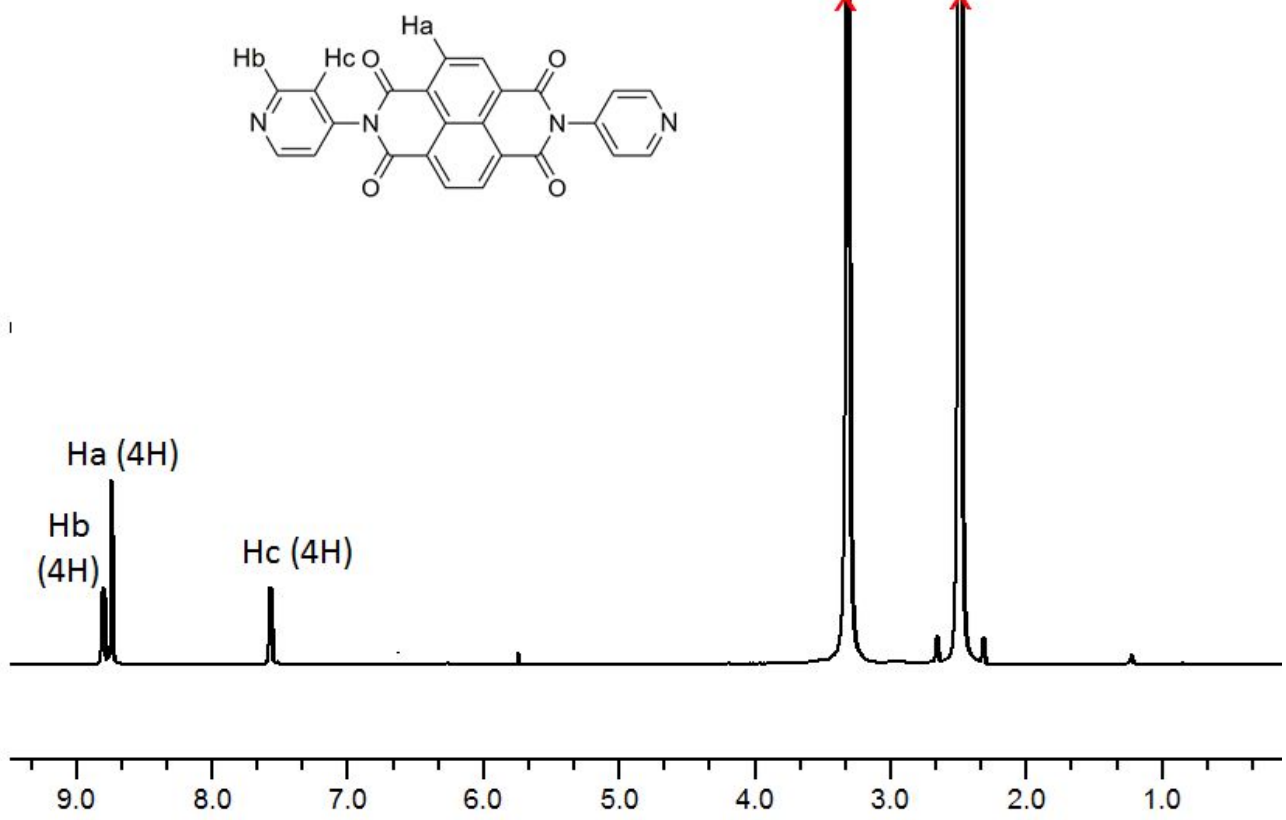

Figure S20: ${ }^{1} \mathrm{H}-\mathrm{NMR}$ spectra of C-2 (solvent DMSO-D6). X indicates solvent peak 


\section{References:}

1. Perrin D. D.; Armarego W. L. F.; Perrin D. R.; Purification of Laboratory Chemicals, 2nd ed., Pergamon, Oxford, 1980.

2. Sikder A.; Sarkar J.; Sakurai T.; Seki S.; Ghosh S. Solvent Switchable Nanostructures and the Function of a $\pi$-Amphiphile. Nanoscale 2018, 10, 3272-3280. 